\title{
Proceeding
}

Supplementary Issue: Winter Conferences of Sports Science. Costa Blanca Sports Science Events, 24 April 2020. Alicante, Spain.

\section{Test and assessment for improvement of the endurance in youth soccer}

\author{
TIZIANA D'ISANTO \\ University of Salerno, Italy
}

\begin{abstract}
The aim of the study was to analyse and estimate how much is the improvement of the performance, on two groups of 15 male among 13-14 years. The group A continue with the trainings during summer period, while the group $B$ does not continue the trainings. The study method is experimental. Data were collected during eight weeks (during summer period). All data detected were expressed as average \pm SD on: height, weight, body mass index (BMI) and Cooper Test. The statistical analysis of the data foresees the use Student T-test for estimate the performance in the two groups in the summer period and between the two groups. The significant differences has been fixed in $p<.05$. The tests that have been made to the male young soccer players, are easy to administer and are intended to investigate two different characteristics of the endurance (general and specific). The results show that there is a significant difference between the two groups in September. For the group $B$ (that do not continue the training during the summer period) there is not a significant difference; while for the group A (that continue the training during summer period) there is a significant difference. These analyse and evaluate of improvement of the performance allow at the coaches of monitor the training process and to design the training load.
\end{abstract}

Keywords: Transition period; Cooper test; Training program; Performance.

Cite this article as:

D'Isanto, T. (2020). Test and assessment for improvement of the endurance in youth soccer. Journal of Human Sport and Exercise, 15(2proc), S200-S205. doi:https://doi.org/10.14198/jhse.2020.15.Proc2.10

Corresponding author. University of Salerno, Italy. http://orcid.org/0000-0001-7151-7486

E-mail: tizidisanto@libero.it

Supplementary Issue: Winter Conferences of Sports Science. Costa Blanca Sports Science Events, 24 April 2020. Alicante, Spain.

JOURNAL OF HUMAN SPORT \& EXERCISE ISSN 1988-5202

(c) Faculty of Education. University of Alicante

doi:10.14198/jhse.2020.15.Proc2.10 


\section{INTRODUCTION}

The soccer is a sport with an high agonistic engagement such to require the development of all the conditional capacities (Altavilla, Raiola, 2019, D'Isanto et al, 2019, Cirillo et al, 2016) and to acquire general and specific motor skills (Di Domenico et al, 2019, Tiziana et al., 2017; Ceruso et al., 2020). Among the different physical qualities needed are the ability to perform straight-line sprint and positive and negative acceleration (di Prampero et al, 2005) with rapid changes of directions, often referred to as agility (Gunnar \& Pettersen, 2015), but also the capacities of endurance (Esposito et al., 2019). The period of time from the end of the championship until September is usually defined as the transition period (Forte, Altavilla, 2018). The transition period (Raiola \& D'Isanto, 2016) is an important phase that usually permit physical and psychological recovery through a complete rest with hanging or decrease (of intensity, volume and frequency) of physical activity (Rago et al, 2017, Coppola, Raiola, 2019, D'Elia et al, 2019). In the last recent years and players run faster, perform technical skills with higher speed and better make tactical decision (Izzo et al, 2019, Alizadeh et al, 2010). Coaches and anyone involved in training prescription of the young soccer player should take in account for these aspects (Silvestri et al., 2019), such as distance covered in order to design specific drills (Altavilla et al, 2017). This study involves the use of Cooper test that has been carried out by young soccer players, easy to administer but able to detect resistance characteristic. The endurance is one of the conditional capacities that constitute the structural prerequisites of the execution of any sporting gesture (Altavilla, 2019). There are various types of exercises that can be distinguished on the basis of intensity and duration. We will have, then, a general endurance (or basic generic), which refers to the player's aerobic qualities, and a more specific endurance, which in addition to aerobic qualities will also refer to anaerobic qualities, the latter in particular linked to the lactic acid metabolism. The aim of the study was to analyse and estimate how much is the improvement of the performance, on two groups of 15 male among 13-14 years, on which have been carried out physical and anthropometric tests (Raiola et al., 2019) at the end of regular season and the beginning of next one.

\section{METHODS}

The study method is experimental and data were collected during eight weeks. The survey was carried out on two groups of 15 male among 13-14 years (group A and group B) and have been carried out physical and anthropometric tests at the end of regular season and the beginning of next one. The physical test that have been chosen is easy to carry out, do not require special equipment and it is useful for quickly obtaining information on large populations. The test that was performed by the young players is the Cooper test. It investigates maximum aerobic power and maximal aerobic speed (VAM). It is a very popular test, which consists of running for 12 minutes with the goal of covering as much distance as possible. The result is given by the distance travelled (Cooper, 1968). It is a power test since there is a significant relationship between the distance travelled in 12 minutes and the maximum aerobic power (expressed in $\mathrm{mL} / \mathrm{kg} / \mathrm{min}$ ). The test was performed out by 12 young soccer players who are part of a soccer school in the "teen" category. The test is carried out on a 7-a-side football field and measures 65 meters long and 40 meters wide. Furthermore, as they are minors, the parents have signed a release in which they declare to take their responsibilities and authorize their children to carry out the Cooper Test. After a comprehensive presentation, on how is carried out and on the its utility, have performed the endurance test. All data detected were expressed as average \pm SD on: height, weight, body mass index (BMI), Cooper Test and has been checked the normality of distribution (KS test). The analysis foresees the use Student T-test for estimate the performance in the two groups in the period July-August and between the two groups. The significant differences has been fixed in $\mathrm{p}<.05$. All statistical analyses were conducted using IBM SPSS Statistics 23. 
Table 1. Anthropometric data.

\begin{tabular}{lcccc}
\hline & \multicolumn{2}{c}{ Group A $(\mathbf{n}=\mathbf{1 5})$} & \multicolumn{2}{c}{ Group B $\mathbf{( n = 1 5 )}$} \\
\hline Age $($ year $)$ & $M$ & SD & $M$ & SD \\
Height $(\mathrm{cm})$ & 14.0 & 3.6 & 14.2 & 3.8 \\
Weight $(\mathrm{Kg})$ & 159.2 & 4.9 & 161.1 & 5.2 \\
BMI $\left(\mathrm{Kg} / \mathrm{m}^{2}\right)$ & 52.6 & 6.1 & 53.1 & 4.2 \\
\hline
\end{tabular}

\section{RESULTS}

The results show in table $6(p=.00)$ that, at the end of the summer period, there is a significant difference between the two groups. For the group $B$ (that not continue the training during the summer period) there is no a significant difference as shown in the table $5(p=.069)$; while for the group $A$ (that continue the training during summer period) there is a significant difference, as shown in the table $4(p=.023)$. These analyse and evaluate the improvement of the performance allow at the coaches of monitor the training process and to design the training load.

Table 2. Results of the Cooper Test (July).

\begin{tabular}{cccccccc}
\hline & \multicolumn{3}{c}{ Cooper Test Group A } & \multicolumn{3}{c}{ Cooper Test Group B } \\
\hline & $\begin{array}{c}\text { Distance } \\
\text { covered }(\mathrm{m})\end{array}$ & $\begin{array}{c}\text { Time } \\
(\mathrm{min} . \text { per km) }\end{array}$ & $\mathrm{VO}_{2}$ max & & $\begin{array}{c}\text { Distance } \\
\text { covered }(\mathrm{m})\end{array}$ & $\begin{array}{c}\text { Time } \\
(\mathrm{min} . \text { per km })\end{array}$ & VO $_{2}$ max \\
\hline 1 & 2100 & 2.71 & 35.66 & 1 & 2200 & 2.91 & 37.66 \\
2 & 2520 & 4.76 & 45.05 & 2 & 2100 & 2.71 & 35.66 \\
3 & 2520 & 4.76 & 45.05 & 3 & 2520 & 4.76 & 45.05 \\
4 & 2940 & 4.28 & 54.43 & 4 & 2520 & 4.76 & 45.05 \\
5 & 2730 & 4.39 & 49.74 & 5 & 2730 & 4.39 & 49.74 \\
6 & 3150 & 3.8 & 59.13 & 6 & 3150 & 3.8 & 59.13 \\
7 & 2520 & 4.76 & 45.05 & 7 & 2520 & 4.76 & 45.05 \\
8 & 3150 & 3.8 & 59.13 & 8 & 3150 & 3.8 & 59.13 \\
9 & 2100 & 2.71 & 35.66 & 9 & 2520 & 4.76 & 35.66 \\
10 & 3150 & 3.8 & 59.13 & 10 & 3150 & 3.8 & 59.13 \\
11 & 2730 & 4.39 & 49.74 & 11 & 2730 & 4.39 & 49.74 \\
12 & 3150 & 3.8 & 59.13 & 12 & 3150 & 3.8 & 59.13 \\
13 & 2100 & 2.71 & 35.66 & 13 & 2200 & 2.91 & 37.66 \\
14 & 2730 & 4.39 & 49.74 & 14 & 2100 & 2.71 & 35.66 \\
15 & 2520 & 4.76 & 45.05 & 15 & 2520 & 4.76 & 45.05 \\
\hline Average & 2680 & 3.98 & 48.75 & Average & 2617 & 3.93 & 46.57 \\
\hline
\end{tabular}


Table 3. Results of the Cooper Test (August).

\begin{tabular}{cccccccc}
\hline & \multicolumn{3}{c}{ Cooper Test Group A } & \multicolumn{3}{c}{ Cooper Test Group B } \\
\hline & $\begin{array}{c}\text { Distance } \\
\text { covered }(\mathrm{m})\end{array}$ & $\begin{array}{c}\text { Time spent } \\
(\mathrm{min} \text { at km) }\end{array}$ & $\mathrm{VO}_{2} \max$ & & $\begin{array}{c}\text { Distance } \\
\text { covered }(\mathrm{m})\end{array}$ & $\begin{array}{c}\text { Time spent } \\
(\mathrm{min} \text { at km) }\end{array}$ & $\mathrm{VO}_{2}$ max \\
\hline 1 & 2200 & 2.91 & 37.66 & 1 & 2200 & 2.91 & 37.66 \\
2 & 2520 & 4.76 & 45.05 & 2 & 2520 & 2.91 & 37.66 \\
3 & 2730 & 4.39 & 49.74 & 3 & 2520 & 4.76 & 45.05 \\
4 & 2940 & 4.08 & 54.43 & 4 & 2520 & 4.76 & 45.05 \\
5 & 2730 & 4.39 & 49.74 & 5 & 2730 & 4.39 & 49.74 \\
6 & 3150 & 3.8 & 59.13 & 6 & 2940 & 4.08 & 54.43 \\
7 & 2730 & 4.39 & 49.74 & 7 & 2520 & 4.76 & 45.05 \\
8 & 3150 & 3.8 & 59.13 & 8 & 2940 & 4.08 & 54.43 \\
9 & 2520 & 4.76 & 45.05 & 9 & 2520 & 4.76 & 35.66 \\
10 & 3150 & 3.8 & 59.13 & 10 & 2940 & 4.08 & 54.43 \\
11 & 2940 & 4.08 & 54.43 & 11 & 2730 & 4.39 & 49.74 \\
12 & 3150 & 3.8 & 59.13 & 12 & 2940 & 4.08 & 54.43 \\
13 & 2520 & 4.76 & 45.05 & 13 & 2200 & 2.91 & 37.66 \\
14 & 2520 & 4.76 & 45.05 & 14 & 2200 & 2.91 & 37.66 \\
15 & 2730 & 4.39 & 49.74 & 15 & 2520 & 4.76 & 45.05 \\
\hline Average & 2778 & 4.19 & 50.81 & Average & 2574.66 & 4.03 & 45.358 \\
\hline
\end{tabular}

Table 4. Difference significant - Group A in the Cooper Test between July - August.

\begin{tabular}{|c|c|c|c|c|c|c|c|c|}
\hline & \multicolumn{5}{|c|}{ Coupled differences } & \multirow{3}{*}{$\mathrm{t}$} & \multirow{3}{*}{$\mathrm{gl}$} & \multirow{3}{*}{ Sign. } \\
\hline & \multirow[t]{2}{*}{ Average } & \multirow[t]{2}{*}{ SD } & \multirow{2}{*}{$\begin{array}{c}\text { Average } \\
\text { standard } \\
\text { error }\end{array}$} & \multicolumn{2}{|c|}{$\begin{array}{c}95 \% \text { confidence } \\
\text { interval difference }\end{array}$} & & & \\
\hline & & & & Inferior & Superior & & & \\
\hline VAR01 - VAR02 & -119.333 & 181.677 & 46.90890 & -219.94291 & -18.72376 & -2.544 & 14 & .023 \\
\hline
\end{tabular}

Table 5. Difference not significant - Group B in the Cooper Test between July - August.

\begin{tabular}{|c|c|c|c|c|c|c|c|c|}
\hline & \multicolumn{5}{|c|}{ Coupled differences } & \multirow{3}{*}{$t$} & \multirow{3}{*}{$\mathrm{gl}$} & \multirow{3}{*}{ Sign. } \\
\hline & \multirow[t]{2}{*}{ Average } & \multirow[t]{2}{*}{ SD } & \multirow{2}{*}{$\begin{array}{l}\text { Average } \\
\text { standard } \\
\text { error }\end{array}$} & \multicolumn{2}{|c|}{$\begin{array}{c}95 \% \text { confidence } \\
\text { interval difference }\end{array}$} & & & \\
\hline & & & & Inferior & Superior & & & \\
\hline VAR01 - VAR02 & 56.00000 & 109.98701 & 28.39852 & -4.90878 & 116.90878 & 1.972 & 14 & .069 \\
\hline
\end{tabular}

Table 6. Difference between two groups for the Cooper Test in September.

\begin{tabular}{|c|c|c|c|c|c|c|c|c|}
\hline & \multicolumn{5}{|c|}{ Coupled differences } & \multirow{3}{*}{$\mathrm{t}$} & \multirow{3}{*}{ gl } & \multirow{3}{*}{ Sign. } \\
\hline & \multirow[t]{2}{*}{ Average } & \multirow[t]{2}{*}{ SD } & \multirow{2}{*}{$\begin{array}{c}\text { Average } \\
\text { standard } \\
\text { error }\end{array}$} & \multicolumn{2}{|c|}{$\begin{array}{l}95 \% \text { confidence } \\
\text { interval difference }\end{array}$} & & & \\
\hline & & & & Inferior & Superior & & & \\
\hline VAR01 - VAR02 & 154.66667 & 119.15576 & 30.76589 & 88.68041 & 220.65293 & 5.027 & 14 & .000 \\
\hline
\end{tabular}




\section{DISCUSSION AND CONCLUSION}

Statistical elaboration of the data has shown that the group $A$, which has continued the training sessions during the summer period (eight weeks), it has had a significant improvement between June and September $(p=.023)$; instead, the group $B$, which has not continued the training session during the summer period, it has not had a significant improvement between June and September $(p=.069)$. Well as, it emerged that the group $A$ has had a significant improvement than at group $B$ at the end of the summer period (September) with $p=.00$. The test is a tool that allows you to have a very effective periodic control and thanks to the analysis of its results and the feedback received it is possible to relate the performance with the work strategies adopted. In order to optimize the monitoring and programming, this study is repeated several times during the competitive season (preparation phase to check periodically whether there are improvements in the physical and technical performances. At the end of the agonistic season it is essential to plan and limit the stop of the players in order to avoid their decreasing physical conditions. This solution would then allow those involved in physical preparation of avoid having this kind of problem (D'elia et al, 2018). A programming must be the result of the functional evaluation of the young athlete. The next step will be to define the modulation of loads during programming to fill in the highlighted gaps or even to further improve the players' best qualities. The conclusion obtained is an invitation to further investigations in order to reach the scientific knowledge that must always be the basis of any training methodology. The results of this study confirm the hypothesis that an excessive rest period leads to a decreasing performance.

\section{REFERENCES}

Alizadeh, R., Hovanloo, F., Safania, A.M. (2010). The relationship between aerobic power and repeated sprint ability in young soccer players with different levels of $\mathrm{VO}_{2}$ max, Journal of Physical Education and Sport, 27 (2): 86-92.

Altavilla, G. (2019). Monitoring training to adequate the teaching method in training: An interpretative concepts, Journal of Physical Education and Sport, 19, pp. 1763-1766.

Altavilla G., Riela L., Di Tore P.A., Raiola G. (2017). The physical effort required from professional football players in different playing positions, Journal of Physical Education and Sport, 17(3):2007-2012.

Altavilla, G., Raiola, G. (2019). A brief review on physiological commitment in basketball: An interpretative key, Journal of Human Sport and Exercise, 14(Proc1), pp. S59-S65. https://doi.org/10.14198/ihse.2019.14.proc1.07

Ceruso, R., Altavilla, G., D'Elia, F. (2020). Evaluation of the coordinative aspects attached to the foundations of the football of the young player, Sport Science 13 (1): 90-94.

Cirillo, G., Nughes, E., Acanfora, A., Altavilla, G., D'Isanto, T. (2016). Physical and sport education testing by quantitative and qualitative tools in assessment in senior school: a proposal, Sport Science, 9(Sup1):97-101.

Coppola, C., Raiola, G. (2019). Interest in $\mathrm{VO}_{2}$ max capacity: Comparing Norwegian and Italian training, Journal of Physical Education and Sport, 19, pp. 1825-1827.

Cooper KH. A means of assessing maximal oxygen uptake. JAMA. 1968; 203:201-4.

D'Elia, F., Mazzeo, F., \& Raiola, G. (2018). The core curriculum in the university training of the teacher of physical education in Italy. Journal of Human Sport and Exercise, 13(2proc), S413-S420. https://doi.org/10.14198/jhse.2018.13.Proc2.25

D'Elia, F., D'Isanto, T., \& Altavilla, G. (2019). Training and performance in the transition period. Journal of Human Sport and Exercise, 14(2proc), S258-S262. https://doi.org/10.14198/ihse.2019.14.Proc2.15 
Di Domenico, F., D'isanto, T., Raiola, G. (2019). Role of speed and agility in the effectiveness of motor performance, Journal of Physical Education and Sport, 19, pp. 1836-1842.

D'Isanto, T., D'Elia, F., Raiola, G., Altavilla, G. (2019). Assessment of sport performance: Theoretical aspects and practical indications, Sport Mont, 17 (1), pp. 79-82.

di Prampero, P.E., Fusi, S., Sepulcri, L., Morin, J.B., Belli, A., Antonutto, G., (2005). Sprint running: a new energetic approach, The Journal of Experimental Biology, 208, 2809-2816. https://doi.org/10.1242/jeb.01700

Esposito, G., Ceruso, R., D'Isanto, T. (2019). Evaluation of some quantitative aspects in the young soccer players training process during puberty. Journal of Physical Education and Sport, 19,1777-1783.

Forte, D., \& Altavilla, G. (2018). Preliminary correlation between anthropometric and performance data in volleyball about the transition period, Journal of Physical Education and Sport, 18 (Suppl. 5): 19941998.

Gunnar, M., \& Pettersen Svein, A. (2015). The effect of speed training on sprint and agility performance in female youth soccer players, Journal of Physical Education and Sport, 15(3): 395-399. https://doi.org/10.1515/ljss-2016-0006

Izzo, R., Giovannelli, M., Raiola, G. (2019). Training load in elite goalkeepers with k-track for monitoring performance, Journal of Physical Education and Sport, 19, pp. 1890-1896.

Jones, A.M., \& Carter, H. (2000). The effect of endurance training on parameters of aerobic fitness, Sports Med, 29(6): 373-386. https://doi.org/10.2165/00007256-200029060-00001

Raiola, G., D'Elia, F., D'Isanto, T., Altavilla, G. (2019). Monitoring and testing motor skills in young soccer players, International Congress of Physical Education, Sports and Kinetotherapy 9 th Edition. https://doi.org/10.35189/iphm.icpesk.2019.37

Rago, V., Pizzuto, F., Raiola, G. (2017). Relationship between intermittent endurance capacity and match performance according to the playing position in sub-19 professional male football players: Preliminary results Journal of Physical Education and Sport, 17 (2), pp. 688-691.

Raiola, G., D'isanto, T. (2016). Assessment of periodization training in soccer, Journal of Human Sport and Exercise, 11 (Proc1), pp. S267-S278. https://doi.org/10.14198/jhse.2016.11.proc1.19

Silvestri, R., Peluso, F., Altavilla, G. (2019). The winning game in the major football leagues, Journal of $\begin{array}{llll}\text { Human Sport and } & \text { Exercise, }\end{array}$ https://doi.org/10.14198/ihse.2019.14.proc4.76

Tiziana, D., Antonetta, M., Gaetano, A. (2017). Health and physical activity, Sport Science, 10(1):100105.

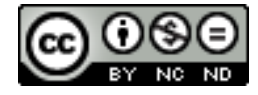

This work is licensed under a Attribution-NonCommercial-NoDerivatives 4.0 International (CC BY-NC-ND 4.0). 